\title{
FORMS AND CONTENTS OF IRON AND ALUMINUM IN INLAND FLOOD PLAINS OF SOUTH-EASTERN NIGERIA
}

\author{
T. O. IBIA
}

Department of Soil Science, Faculty of Agriculture, University of Uyo. P.M.B 1017, Uyo, Nigeria.

\begin{abstract}
Fourteen representative soils from inland flood plains in Southeastern Nigeria were studied to characterise forms (crystalline and amorphous) contents in iron and aluminium oxides. Total iron and aluminium, extracted using $\mathrm{HCl}$ after fusion with $\mathrm{Na}_{2} \mathrm{CO}_{3}$, ranged from 1.25 to $7.74 \%$ by weight of dry soil, with a mean of $3.29 \%$ for total $\mathrm{Fe}_{2} \mathrm{O}_{3}$ and from 9.75 to $44.67 \%$ with a mean of $26.04 \%$ for total $\mathrm{Al}_{2} \mathrm{O}_{3}$. Broad textural grouping of the soils showed mean total contents of $\mathrm{Fe}_{2} \mathrm{O}_{3}$ and $\mathrm{Al}_{2} \mathrm{O}_{3}$ comparable to fine-textural soil, medium-textured soil, and coarse-textured soil. On the basis of drainage, mean contents of total iron and aluminum are, in a decreasing order : very poorly drained, poorly drained and imperfectly drained soil. Total free oxides (DCB extractable forms) averaged 0.59 and $0.16 \%$, for $\mathrm{DCB} \mathrm{Fe}_{2} \mathrm{O}_{3}$ and $\mathrm{DCB} \mathrm{Al}_{2} \mathrm{O}_{3}$, respectively. The fine texture soil gave the highest mean value ( $0.90 \%)$ for $\mathrm{DCB} \mathrm{Fe}_{2} \mathrm{O}_{3}$, as compared to medium and coarse texture soils. Generally, values of oxalate extractable and pyrophosphate extractable $\mathrm{Fe}_{2} \mathrm{O}_{3}$ were relatively low. The reactivity of the sesquioxides, measured using the ratio of oxalate extractable-to dithionite extractable iron and aluminum, tended to be high, indicating that much of the total free oxides exists mainly in the form of amorphous oxides and, which, impeded drainage. Active ratios of $\mathrm{Al}_{2} \mathrm{O}_{3}$ were generally higher than those of $\mathrm{Fe}_{2} \mathrm{O}_{3}$. The extractability of total free iron ranged from 8.50 to $25.3 \%$ while that of aluminum ranged from 0.26 to $1.84 \%$, suggesting a relatively less weathering of these inland plain soils (Wetland soils).
\end{abstract}

Key-words : Aluminum, iron, soil, inland flood plains, Nigeria.

\section{RESUME}

FORMES ET TENEURS EN FER ET EN ALIMINIUM DES PLAINES DES BAS-FONDS DU SUD-EST DU NIGERIA

Quatorze sols représentatifs des bas-fonds du Sud-Est du Nigeria ont été utilisés dans cette étude. Des échantillons de sols ont été caracteristisés au laboratoire pour déterminer les formes et les teneurs en oxydes, fer et aliminium libres. La teneur en fer et aliminium extractible par $\mathrm{HCl}$, après fusion, avec $\mathrm{Na}_{2} \mathrm{CO}_{3}$, a varié de 1,25 à 7,74\% par poids de sol sec, avec une moyenne de 3,29\% pour $\mathrm{Fe}_{2} \mathrm{O}_{3}$ total et de 9,75 à 44,67\% avec une moyenne de $26,04 \%$ pour $\mathrm{Al}_{2} \mathrm{O}_{3}$ total. Une classification approximative des sols montre des teneurs moyennes de $\mathrm{Fe}_{2} \mathrm{O}_{3}$ et $\mathrm{Al}_{2} \mathrm{O}_{3}$ de l'ordre de sol à texture fine, sol à texture moyenne et sol à texture grossière. Sur la base du drainage, la teneur moyenne en fer total et en aliminium est par ordre décroissant : trés faiblement drainé, faiblement drainé, anormalement drainé. Les teneurs totales en oxydes (formes extractable au DCB) ont été en moyenne de 0,59 et 0,16\%, pour $D C B \mathrm{Fe}_{2} \mathrm{O}_{3}$ en $D C B \mathrm{Al}_{2} \mathrm{O}_{3}$, respectivement. Les sols à texture fine ont présenté les moyennes les plus élevées (0,90\%) pour $D C B \mathrm{Fe}_{2} \mathrm{O}_{3^{\prime}}$ par rapport aux sols à texture moyenne et grossière. De façon générale, les teneurs en $\mathrm{Fe}_{2} \mathrm{O}_{3}$ extractables à l'oxalate et au pyrophosphate ont été relativement faibles. La réactivité des sesaquioxydes mesurée par la fraction de fer et d'aliminium extractable à l'oxalate, d'une part, et au dithionte d'autre part, tend à être élevé. Ce qui est la preuve qu'une bonne partie des oxydes libres existe sous forme amorphe, à cause du mauvais drainage. Les ratios de $\mathrm{Al}_{2} \mathrm{O}_{3}$ actif ont été généralement plus élevés que ceux de $\mathrm{Fe}_{2} \mathrm{O}_{3}$. L'extractabilité du fer libre total a varié de 8,80 à $25,3 \%$ tandis que celle de l'Aliminium varie de 0,26 à $1,84 \%$ temoignant ainsi d'une altération relativement faible de ces sols de bas-fonds (sols humides).

Mots clés : Aluminium, fer, sol, bas-fonds, Nigeria. 


\section{INTRODUCTION}

Inland flood plains occupy a sizeable portion of South-eastern Nigeria. The area is drained by Cross River, Enyong Creek, and Ikpa River. The soils are mainly hydromorphic, occurring in fresh water swamps, flood plains and catchments. These soils have not been adequately studied.

Forms of iron and aluminum are important parameters for a proper understanding of these soils. The content and distribution in the soils are known to influence some soil properties such as anions adsorption, surface charges, specific surface area, swelling and aggregate formation, nutrient transformation and pollutants retention (Aghimien et al., 1988 ; Deshpande et al., 1968 ; Greenland et al., 1968). The various forms have been extracted using different reagents (Mc Keague and Day, 1966 ; Blume and Schwertman, 1969). Dithionite extractable iron has been widely considered to give a reasonable estimate of pedogenic free iron in soils while oxalate extractable represents amorphous forms of iron and aluminum and the differences between the two chemical forms give a measure of crystalline iron and aluminum oxides in soils.

These amorphous and crystalline oxides occurring in soils could be used in the understanding of the genesis, properties and classification of the soils, particularly in the tropics. Their have been used to identify diagnostic horizons (McKeague and Day, 1966), while Alexander (1974) used the same parameter to estimate the age of soils he studied. A constant dithionite extractable $\mathrm{Fe}_{2} \mathrm{O}_{3}$ to clay ratio with depth reported by Juo (1981) indicates a downward migration of iron oxides and clays (Omenihu et al., 1984).

The reactivity of these sesquioxides are usually assessed by the value of the active ratios. Soils with poor drainage conditions have been reported to have high active ratios and therefore, more reactive (Aghimien et al., 1988).

The objectives of this study are to examine the content and forms (Crystaline or amorphous) of iron and aluminum in the soils of some inland flood plains in South eastern Nigeria to and relate these forms to drainage conditions as well as the broad textural grouping of the soils using fourteen representative soil pedons.

\section{MATERIAL AND METHODS}

Fourteen soil profiles located in the flood plains of the Cross River, Southeastern Nigeria, were studied. The area is in the rain forest zone with a mean annual rainfall of over $3000 \mathrm{~mm}$. The soils are formed from coastal plain sand, alluvial and shale-rich sediments. Their broad classification and physical characteristics are given in Table 1 (Ibia, 1995).

The profiles were dug and sampled. The soil samples were air-dried and sieved through a 2 $\mathrm{mm}$-sieve. Sub-samples were crushed and further sieved through a 100 mesh-sieve for the determination of the various forms of iron and aluminum.

Table 1 : Some physical characteristics of soils from the inland floodplains of South-Eastern Nigeria.

Quelques caractéristiques physiques des sols de bas-fonds au Sud-Est du Nigeria.

\begin{tabular}{lclcccl}
\hline \multirow{2}{*}{ Soil sample } & $\begin{array}{c}\text { Profile Depth } \\
(\mathrm{Cm})\end{array}$ & \multirow{2}{*}{ Drainage } & \multicolumn{2}{c}{ Particle Size Distribution (\%) } & \multirow{2}{*}{ Texture } \\
\cline { 5 - 6 } & $0-36$ & Imperfectly drained & 48.8 & 16.2 & 35.0 & Sandy clay \\
EN31 & $0-46$ & Imperfectly drained & 53.1 & 22.4 & 24.5 & Sandy clay loam \\
EN32 & $0-45$ & Imperfectly drained & 64.2 & 17.2 & 18.6 & Sandy loam \\
EN33 & $0-42$ & Poorly drained & 25.0 & 16.0 & 59.0 & Clay \\
EN51 & $0-50$ & Poorly drained & 50.0 & 26.4 & 23.6 & Sandy clay loam \\
EN52 & $0-40$ & Poorly drained & 41.0 & 27.6 & 31.4 & Clay loam \\
EN53 & $0-30$ & Poorly drained & 43.0 & 24.2 & 32.8 & Clay loam \\
EN54 & $0-50$ & Poorly drained & 86.2 & 5.8 & 8.0 & Loamy sand \\
EN61 & $0-50$ & Very poorly drained & 4.2 & 31.0 & 64.8 & Clay \\
EN71 & $0-50$ & Very poorly drained & 46.8 & 16.6 & 36.6 & Sandy clay \\
EN72 & $0-50$ & Very poorly drained & 28.4 & 35.6 & 36.0 & Clay loam \\
EN73 & $0-51$ & Very poorly drained & 75.8 & 6.0 & 18.2 & Sandy loam \\
EN74 & $0-40$ & Very poorly drained & 53.2 & 32.0 & 14.8 & Loam \\
EN75 & $0-40$ & Very poorly drained & 14.2 & 38.8 & 47.0 & Clay \\
EN81 & & & & & &
\end{tabular}

Adapted from: Ibia, 1995.

EN 31 - EN 81 = Soil Code used in field sampling 


\section{ANALYTICAL PROCEDURE}

Particle size was determined using the hydrometer method with Calgon (Sodium hexametaphophate) as the dispersing agent (IITA, 1979). Forms of iron and aluminum were first extracted using various methods. Free oxides (dithionite $\mathrm{Fe}_{2} \mathrm{O}_{3}$ and $\mathrm{Al}_{2} \mathrm{O}_{3}$ ) were extracted with the dithionite-citrate-bicarbonate (DCB) solution. (Mehra and Jackson, 1960). The amorphous oxides (oxalate $\mathrm{Fe}_{2} \mathrm{O}_{3}$ and $\mathrm{Al}_{2} \mathrm{O}_{3}$ ) were extracted using conc. ammonum oxalate solution (McKeague and Day, 1966). The procedure using pyrophosphate solution described by McKeague (1967), was employed to extract organic forms of iron and aluminum.

Total iron and aluminum in the soils were extracted with dilute $\mathrm{HCl}$ after fusion with $\mathrm{Na}_{2} \mathrm{CO}_{3}$. All forms of iron and aluminum (DCBextractable, Oxalate-extractable, pyrophosphate-extractable and $\mathrm{HCl}$-extractable) were measured colorimetrically following extraction using the ortho-phenanthroline method for iron (Jackson, 1969) and the modified aluminon method for aluminum (Black, 1967).

\section{RESULTS AND DISCUSSION}

Results on the physico-chemical properties of the soils studied have been published elsewhere (Ibia, 1995). The soils were grouped into three drainage classes namely: Imperfectly drained, poorly drained and very poorly drained soils based on the outline by FAO (1986)

Three broad textural groupings (Soil Survey Staff, 1990) were used as shown in Table 1 and defined as follows :

Fine-textured soils : clays, silty clays, sandy clays, clay loam and silty clay loam, with more than $35 \%$ clay.

Medium-textured soils : sandy loam, loam, sandy clay loam, silt loam, silt, silty clay loam and clay loam with less than $35 \%$ clay and less than $65 \%$ sand. The sand fraction may be as high as $82 \%$ when a minimum of $18 \%$ clay is present.

coarse-textured soils : sand, loamy sand and sandy loam with less than $18 \%$ clay and more than $65 \%$ sand.

The soils were shown to be generally acidic $(\mathrm{pH}$ 4.72-5.67), with possible iron and aluminum toxicity problems and low contents of available $\mathrm{P}$ and exchangeable $\mathrm{K}$.

Table 2 shows profile contents of the various forms of iron and aluminum. Contents of total iron ranged from 1.35 to $7.74 \%$ and total aluminum from 9.75 to $44.67 \%$ in the samples. These ranges fell within the limits obtained by Aghimien et al., (1988) in some hydromorphic soils in Nigeria. The values were however, relatively lower than those obtained by Udo (1980) in well drained profiles.

When data were grouped into textural classes (Table 3), mean total iron contents ranged from 2.61 to $4.49 \%$, the trend being, content in fine textured soils, medium textured soils, coarse textured soils. This trend was also observed for total aluminum contents which ranged from $19.93 \%$ in coarse textured soil to $33.39 \%$ in the fine textured soils. Aghimien et al., (1988) showed that total iron content in the soils they studied tended to be influenced largely by clay and silt fractions. On the basis of drainage class (Table 4), very poorly drained profiles gave highest mean values for total iron and aluminum (3.74 and 32.68) contents followed by poorly drained profiles (3.36 and 23.86) followed by imperfectly drained soils (2.48 and 19.36).

Dithionite Citric Bicarbonate extractable, oxalate extractable and pyrophosphate extractable forms of iron and aluminum are presented in table 2 . For dithionite extractable $\mathrm{Fe}_{2} \mathrm{O}_{3}$, the mean values ranged from 0.14 to 1.46 and for $\mathrm{Al}_{2} \mathrm{O}_{3}$ it ranged from 0.10 to 0.24 . Content $\mathrm{Fe}_{2} \mathrm{O}_{3}$ appeared to be higher in fine textured soils with a mean of $0.90 \%$ than in medium and coarse textured class. Higher mean value were also recorded for very poorly drained and imperfectly drained soil classes.

Generally the mean values of oxalate extractable and pyrophosphate extractable $\mathrm{Fe}_{2} \mathrm{O}_{3}$ and $\mathrm{Al}_{2} \mathrm{O}_{3}$ were low. Oxalate $\mathrm{Fe}_{2} \mathrm{O}_{3}$ ranged from 0.08 to 0.32 , while pyrophosphate forms ranged from 0.03 to 0.18 . For $\mathrm{Al}_{2} \mathrm{O}_{3}$, the values ranged from 0.02 to $0.09 \%$ for oxalate extractable forms and from 0.14 to 0.63 for pyrophosphate extractable forms. The generally low extractable values of the various forms of the sesquioxides have been attributed to the poor drainage conditions of the soils which prevent strong weathering and subsequent formation of sesquioxides in these soils (Aghimien et al., 1988). 


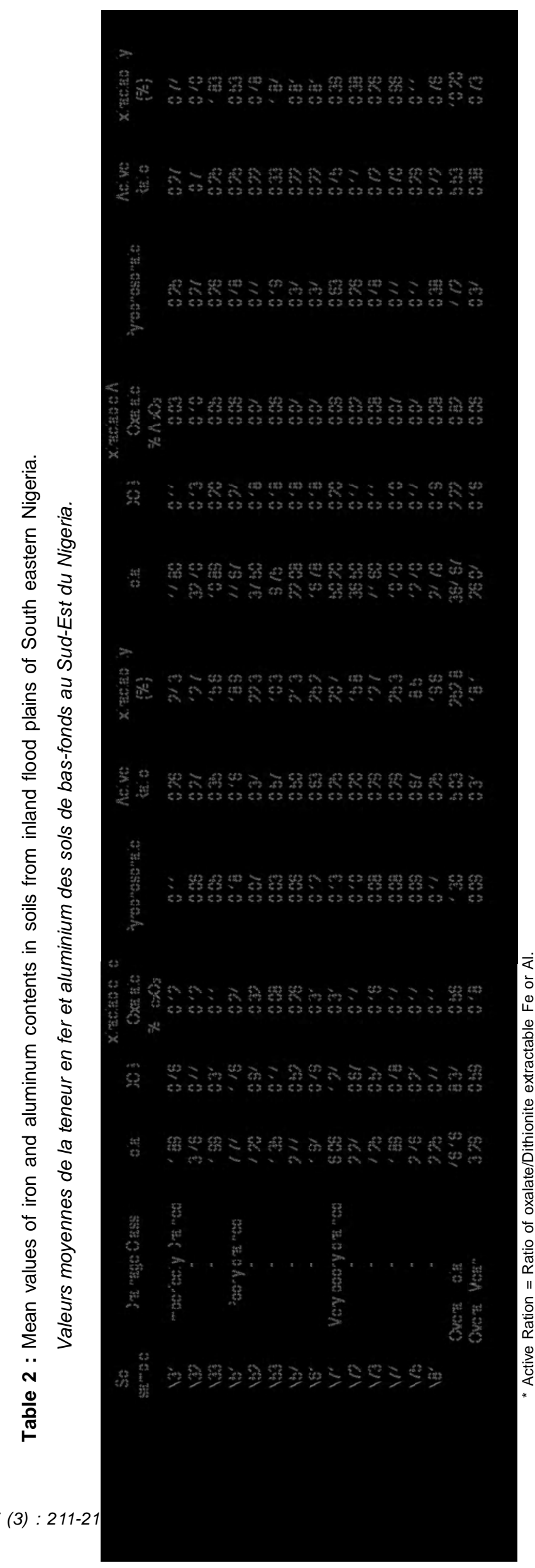


Oxalate and dithionite extractable iron and aluminum, as well as their various ratios of these cations, have been used to evaluate soil development and weathering (Omenihu et al., 1994). The ratios of oxalate extractable iron and of aluminum to dithionite extractable forms, which are a measure of the reactivity of the sesquioxides, indicate the relative amount of poorly ordered and crystalline iron and aluminium compounds in the soil (Blume and Schwertmann, 1969). Active iron ratios ranged from 0.16 to 0.67 when all the soils studied are pooled together (Table 2). The mean values are comparable to those (0.20 to 0.67$)$ obtained by Aghimien et al., (1988) in some hydromorphic soils of southern Nigeria but relatively higher than values obtained by Omenihu et al., (1994) in well drained coastal plain sand soils of Southern Nigeria. Udo (1980) also obtained values for iron ratio ranging from 0.03 to 0.13 in well-drained Nigerian soils, as compared to values of 0.36 to 0.99 in poorly drained profiles from Nigeria. Generally, the activity of iron is known not to exceed 0.33 in well drained soils (Mc Keague and Day, 1966) whereas, Stonehouse and St. Arnaud (1971) obtained high or iron ratios, which were generally above 0.33 in poorly drained soils. Whereas, for these wetland flood plains under study, active iron ratios varied from within the limits to double the limits ; particularly in coarse texture soils (Table 3) and poorly-drained profiles (Table 4). According to Schwertmman (1964), a higher iron reactivity indicates lower degree of ageing of the minerals, pointing to the fact that the rate of iron release from the primary mineral lattices seems to exceed the rate of iron crystallization. The relatively high active iron ratios in these soils show that a large fraction of the total free oxides exists, mainly in the amorphous, rather than the crystalline forms and that, impeded drainage, reduces crystallization of iron minerals.

Active ratios of $\mathrm{Al}_{2} \mathrm{O}_{3}$ were higher than those of $\mathrm{Fe}_{2} \mathrm{O}_{3}$ and ranged from 0.22 to 0.77 and were relatively higher than those obtained by Aghimien et al., (1988), which ranged from 0.09 to 0.35 . When considered on broad textural grouping, the active aluminum ratio gave a highest mean value of 0.54 in medium-textured soils, as compared to fine-textured soils (Table 3). The relatively higher aluminum ratios indicates the presence of higher amounts of amorphous forms of aluminum oxides than iron oxides in the soils.

Extractability of the various oxides, which is the ratio of the total free oxides (DCB extractable iron or aluminum) to total content of iron and aluminum, is a useful index for evaluating the degree of soils weathering. The extractability of total free iron ranged from 8.50 to $29.2 \%$, while that of aluminum ranged from 0.26 to $1.84 \%$ in all the soils studied (Table 2).

These results seem to suggest that the soils are relatively less weathered, a feature of most hydromorphic soils. Udo (1980) obtained iron extractability values higher than $50 \%$ in some well drained soils formed on basement complex rocks, whereas for poorly drained ones, average extractability was only $10 \%$. 


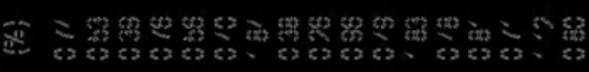

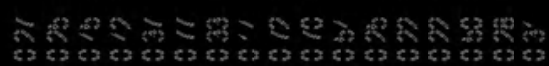

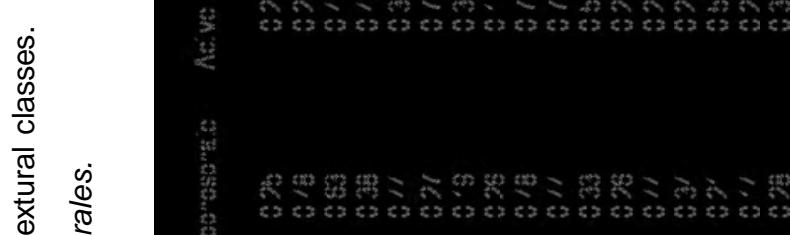

依

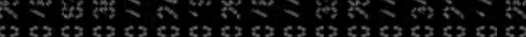

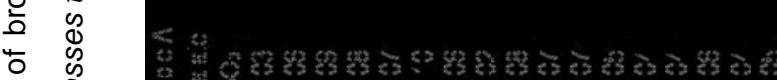

穴 $\frac{\pi}{U}$

은 v

秀 $\frac{0}{0}$

ช

๘)

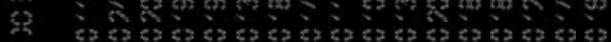

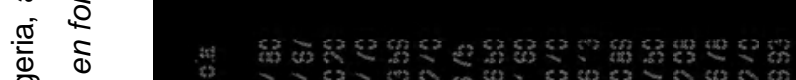

每 ब

ᄃ

崩 ш ठ

兵

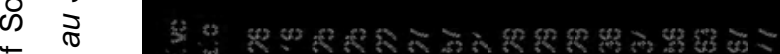

(1)

$\stackrel{\mathscr{C}}{\frac{\mathbb{C}}{\overparen{T}}}$

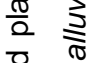

응

으 $\stackrel{\frac{0}{5}}{\stackrel{5}{5}}$

它

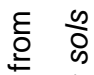

w

के

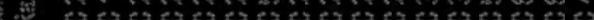

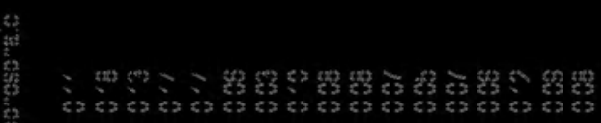

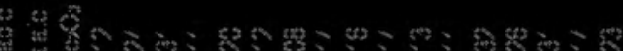

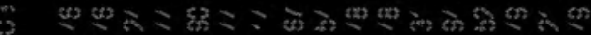

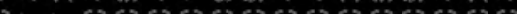

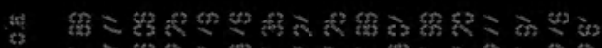

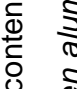

ह

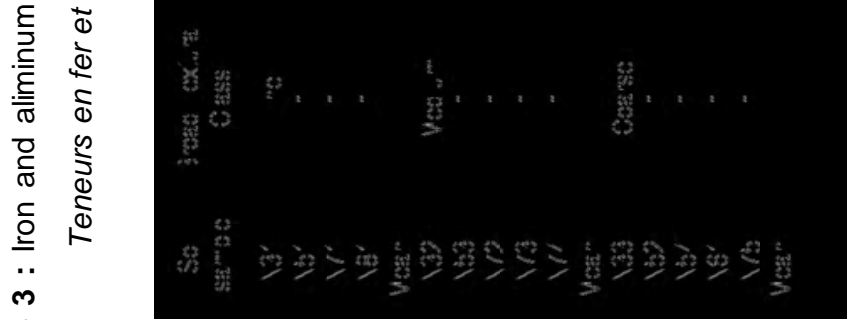

$\frac{0}{\frac{0}{\sigma}}$ 


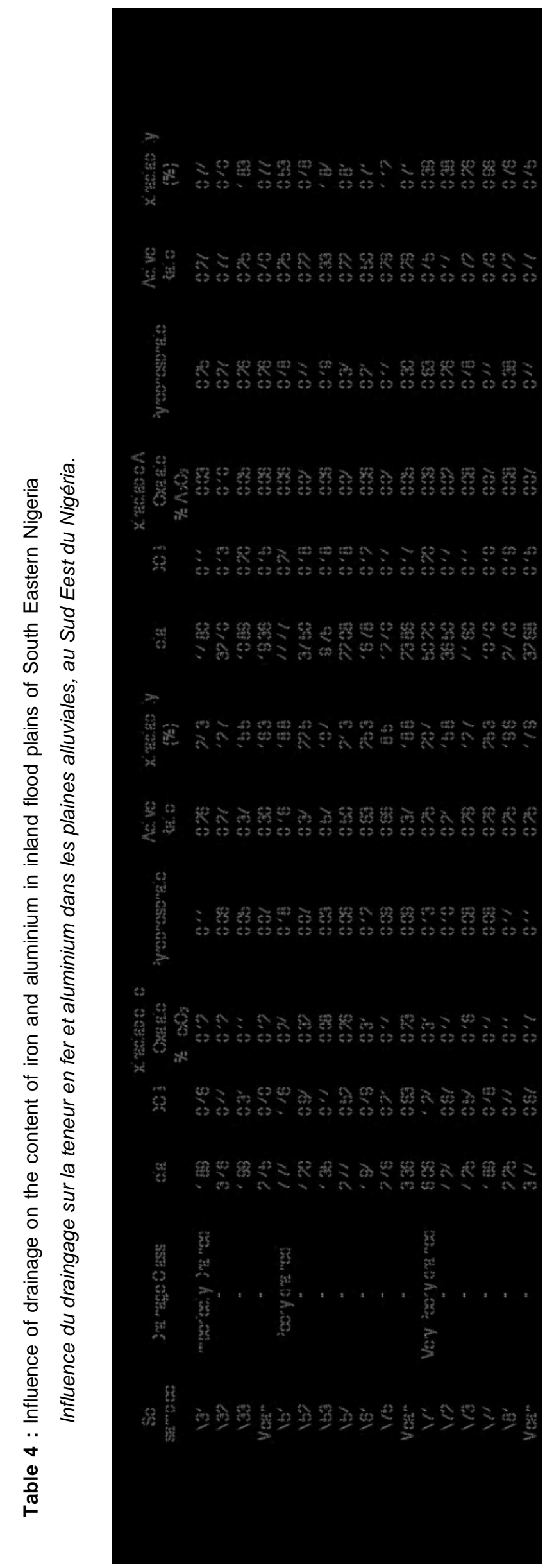

Agronomie Africaine 17 (3) : 211-218 (2005) 


\section{REFERENCES}

Aghimien (E. A.), Udo (E. J.) and (O.) Ataga. 1988. Profile distribution of forms of iron and aluminum in the hydromorphic soils of southern Nigeria. J.W. Afri. Sci. Assoc. 31 : 57-70.

Alexander (E. B.). 1974. Extractable iron in relation to age on terraces along the Truckee River Nevada. Soil Sci. Soc. Am Proc. 38 : 121 124.

Black (C. A). 1967. Methods of Soil Analysis 11, ASA Monograph, Madison, Wisc.

Blume (H. P.) and (U.) Schwertmann. 1969. Genetic evaluation of profiles distribution of $\mathrm{Al}, \mathrm{Fe}$, and Mn oxides. Soil Sci. Soc. Am. Proc. 33 : 438-444.

Deshpande (T. L.), Greenland (D. J.) and (J. P.) Quirk. 1968. Changes in soil properties associated with the removal of iron and aluminum oxides J. Soil Sci. 19 : 108122.

FAO. 1986. Soil Map of the World, Revised Legend, World Soil Resources, Report 60. FOA, Rome.

Greenland (D. L.), Oades (J. M.) and (T. J.) Shertwin. 1968. Electronic microscope observations of iron oxides in some red soils. J. Soil Sci, 19 : 166-122.

Ibia (T. O.). 1995. Inland Swamps of Akwa Ibom State, their characteristics, potentials and constraints to development : In : African Soils : rehabilitation and management of african soils for sustainable productivity and Envi-ronmental Protection. (A.A. Agboola Ed.) OAU/STRC ; Special Edition Vol. 28 : 551-561.

IITA. 1979. Selected Methods for soil and plant Analysis ; Manual Series 1. International Institute of Tropical Agriculture, Ibadan, Nigeria.
Jackson (M. L.). 1969. Soil Chemical Analysis. An Advanced Course. University of Wisconsin, Madison, Wisc. Pp. 47 - 58.

Juo (A. S. R.). 1981. Mineralogical groupings of soils with variable charge in relation to management and classification. International Conference on Soils with Variable Charges. Palmerston North, New Zealand.

McKeague (J. A.). 1967. An evaluation of $0.1 \mathrm{M}$ pyrophosphate-dithionite in comparison with oxalate as extractants of the accumulation products in Podzols and some other soils. Can J. Soil Sci. $47: 95$ 99.

McKeague (J. A.) and (J. H.) Day. 1966. Dithionite and Oxalate iron and aluminum as aids in differentiating various classes of soils. Can J. Soil Sci ; $46: 13-22$.

Mehra (O. P.) and (M. L.) Jackson. 1960. Iron Oxide removal from soils and clays by a dithionite citrate system buffered with sodium bicarbonate. Clays clay Min. 7 : 317-327.

Omenihu (A. A.), Opuwaribo (E. E.) and (P. M.) Sutton. 1994. Forms of extractable iron and aluminum oxides in coastal plain soils of south eastern Nigeria. $21^{\text {st }}$ Annual Conf. of Soil Sci. of Nigeria. University of Uyo, Nigeria. 30 $0^{\text {th }}$ Jan - $4^{\text {th }}$ Feb. 1994.

Schwertmann (U.) 1964. The differentiation of iron oxide in soils by photochemical extraction with acid ammonum-oxalate. Z. Pflanzends Dungs ; Bonekol. 105 : 194-202.

Soil Survey Staff. 1990. Soil Survey Manual, USDASCS, US Government Print Office Washington DC.

Stonehouse (H. B.) and (R. J.) St. Arnaud. 1971. Distribution of iron, clay and extractable iron and aluminum in some Saskatchewan Soils. Can J. Soil Sci. 51 : 283 - 292.

Udo (E. J.). 1980. Profile distribution of iron sesquioxides in selected Nigerian soils. J. Agric. Sci. 95 : 191-198. 